\title{
Economics of religion on trial: how disestablishment did not lead to religious revival in the Swiss cantons of Geneva and Neuchâtel
}

\author{
Jörg Stolz
}

\begin{abstract}
According to ideas in contemporary economics of religion, religious disestablishment will lead to religious vitality: more strictness, more evangelising, and more growth. The present article puts this theory to the test by inspecting the historical record (1900 to the present) of the two Swiss cantons where disestablishment went farthestGeneva and Neuchâtel-and by comparing them to other Swiss cantons where church and state remained closely linked. I find that the predictions of the economic model are not corroborated. Formerly established churches did not become stricter, did show increased, but relatively unsuccessful marketing efforts, did not grow, and became very poor financially. Non-established churches did not seem to benefit in any way from the disestablishment. The article makes four specific theoretical points that explain why this was the case.
\end{abstract}

\section{ARTICLE HISTORY}

Received 1 December 2016

Accepted 9 April 2017

\section{KEYWORDS}

Establishment of religion; regulation of religion; economics of religion; secularisation

In Zurich, the road cleaners are better paid than our pastors.

(Henri de Morsier, Eglise Protestante de Genève)

\section{Introduction}

According to influential ideas in contemporary economics of religion, religious disestablishment will lead to religious vitality (Stark and Iannaccone 1994; Stark and Finke 2000). ${ }^{1}$ In other words, a situation in which some religious groups are established, while others are not depresses overall religiosity in a given region or country; abolishing this establishment will therefore-according to this theory-lead to religious revival. I put this theory to the test by inspecting the historical record (1900 to the present) of the disestablishment of religion in the two Swiss cantons where disestablishment went farthestGeneva and Neuchâtel-and by comparing them to other Swiss cantons where church and state remained closely linked.

Switzerland is an especially appropriate country in which to study this theory, since its federalist history has created substantial variation in church-state relationships across its 26 cantons, providing a natural experiment for social scientists (Pahud de Mortanges 2007). Starting with a very strong state-church system, there has been a trend towards 
disestablishment in all cantons. However, the speed and the nature of disestablishment have varied tremendously, leading some cantons to keep a very strong, others an intermediate tie, and two cantons-Geneva and Neuchâtel-to develop extremely weak ties between church and state (Stolz et al. 2016, 46-47). Hence we should observe-according to economic theory-an especially strong upswing of religious vitality in these two cantons.

I find that the predictions of the economic model are not corroborated. Formerly established churches did not become stricter, showed increased, but relatively unsuccessful marketing efforts, did not grow, and became very poor financially. Non-established churches did not seem to benefit in any way from the disestablishment. Overall, secularisation occurred in the cantons of Geneva and Neuchâtel just as it did in the other Swiss cantons.

On the basis of in-depth knowledge of the cases of Geneva and Neuchâtel, this article makes four theoretical points that explain just why disestablished churches did not become stricter (although some church leaders would have liked them to do so), why their increased evangelising and folk-church marketing failed, why there was no increased overall religious vitality, and why formerly established churches became so poor financially. These points may have a more general application.

Regarding methods, I rely on the scholarly literature on religion in the two cantons of Geneva and Neuchâtel from 1900 to the present, supplemented by interviews with historians Frédéric Amsler, Sophie Scholl, and Michel Grandjean. Furthermore, I draw on: (1) statistical data collected by Michael Marti, Eliane Kraft, and Felix Walter (Marti, Kraft, and Walter 2010), (2) the Swiss censuses (Bovay 2004), (3) the Swiss national congregation census (Monnot and Stolz 2014), (4) the representative International Social Survey Programme (ISSP)/Religion et lien social (RLS) data for Switzerland (Campiche 2004).

This article is a companion to the study by Jörg Stolz and Mark Chaves (Stolz and Chaves 2017), which used cross-sectional representative quantitative data on the congregational level as well as a general historical account of state-church relations in Switzerland to show that differences in the degree of religious regulation at the canton level did not affect religious vitality for the entire range of Swiss cantons. This article extends and deepens the argument, by focusing on the historical developments in the Swiss cantons of Geneva and Neuchâtel. The contribution of this article is that it goes much deeper into the history than the companion article was able to do, thus describing the specific historical developments that explain just why the intriguing theory by modern economists of religion fails in these two cases.

I first present the theory by economists of religion, then show how churches were disestablished in the cantons of Geneva and Neuchâtel. This is followed by analyses of the effects of disestablishment on selected dimensions of religious vitality: strictness, evangelisation, attendance, growth, and income. The article concludes with a summary of the four points that (partly) explain the findings.

\section{Theory}

The core idea that establishment ${ }^{2}$ negatively affects religious vitality goes back at least to Adam Smith, who believed that

The teachers of [religion], in the same manner as other teachers, may either depend altogether for their subsistence upon the voluntary contributions of their hearers; or they may derive it from some other fund to which the law of their country may entitle them [...]. Their exertion, 
their zeal and industry, are likely to be much greater in the former situation than the latter. (Smith [1776] 2008, 564)

More recently, scholars advocating an economic approach to religion have claimed that the mechanisms identified by Smith accounted for major differences in religiosity across a wide range of past and present settings (Iannaccone 1991, 159-161, 1998, 1485-1487; Stark and Finke 2000, 193-195). Starting with the idea that religious demand is stable across all societies, these researchers maintain that the establishment of religion depresses religious vitality for at least two reasons: firstly, established religious groups are under less competitive pressure and therefore produce less varied religious goods, and goods of lower quality, creating less overall consumption of those goods by consumers. One of the reasons for the low quality of religious goods of established groups is-again, according to economists of religion-their theological and moral laxity, which leads to a generalised problem of free-riding and a culture of low-key belief and practice (Iannaccone 1994, 1181-1183). ${ }^{3}$ Secondly, non-established religious groups are 'crowded out' of the market, since they must compete against subsidised religious goods by established competitors. Thus, in a situation of establishment, consumers have less control over the quantity and quality of religious goods and therefore consume less. Disestablishment should have the opposite effects and lead to greater religious vitality. Rodney Stark and Laurence Iannaccone (Stark and Iannaccone 1994) applied this theory to Europe and predicted that disestablishment (or 'desacralization', as they call it) would lead to a general religious revival in the long run.

There have been numerous points of criticism of the economic approach, both theoretical (Bruce 1999, 1993; Spickard 1998) and empirical (Chaves and Gorski 2001; Voas, Olson, and Crockett 2002; Chaves and Cann 1992; Pollack and Rosta 2015; Stolz 2009; for a relatively recent overview, see De Graaf 2013). This criticism notwithstanding, the idea that disestablishment leads to religious vitality remains influential (Fox and Tabory 2008; McCleary and Barro 2006).

One of the shortcomings of most empirical tests of the economics of religion approach has been that most advocates and critics have only tested it with individual-level data, assuming that their individual-level results would reflect differences between established and non-established congregations. ${ }^{4}$ Yet, the economics of religion approach is at its heart a model that links the behaviour of suppliers and consumers and thus studies that investigate both have a distinctive advantage. One such study is by Frank Lechner (Lechner 1996a) who shows with data both on the individual and organisational level that, in the Netherlands, starting in the 1960s, deregulation (depillarisation) was not accompanied by religious revival, but - on the contrary-by strong secularisation. ${ }^{5}$ While Lechner's account is convincing, it could be argued that there may be non-observed special factors concerning only the Netherlands that might have masked the overall positive relationship between deregulation and religious revival.

The present article goes one step further by providing a quasi-experiment of the relationship between disestablishment and religious revival. The two Swiss cantons analysed here are very similar in many respects to other Swiss cantons, but with the one difference that establishment has been (almost completely) abolished.

The key contribution of this article lies in the in-depth description of the reasons why the mechanisms suggested by representatives of economics of religion did not work in the two case studies. This, in turn, leads me to identify four theoretical points concerning 
strictness, evangelising, religious vitality, and church financing that may have a more general application.

\section{Disestablishment in Geneva and Neuchâtel}

The cantons of Geneva and Neuchâtel are two of the western French-speaking cantons. They have both known times when they were almost exclusively Protestant (Reformed), but because of religious pluralisation and secularisation, in 2015, only $9.4 \%$ of the population of Geneva and only $21.1 \%$ of the population of Neuchâtel were still Protestant (Reformed); the percentage of nones in both cantons has become larger than the largest confessional group (see Table 1).

While there has been a slow trend towards disestablishment in all the Swiss cantons since the nineteenth century, in most Swiss cantons, there is still a strong or intermediate link between church and state, in other words, a form of establishment. The two cantons of Geneva and Neuchâtel, however, have known very far-reaching forms of disestablishment and are known as the 'separation' cantons. Their score using an adapted Chaves-Cann style scale of religious regulation is at 1 (Geneva) and 2 (Neuchâtel), below all other Swiss cantons, while, for example, cantons like Bern or Zurich reach a score of 8 (see Table 1; see Appendix 1 for the scale).

Table 1. Confessional composition and strength of establishment of Swiss cantons.

\begin{tabular}{|c|c|c|c|c|c|c|c|}
\hline & \multicolumn{6}{|c|}{ Confessional composition, $2015^{(1)}$} & \multirow[b]{2}{*}{$\begin{array}{c}\text { Strength } \\
\text { Establishment } \\
\left({ }^{(2)}\right.\end{array}$} \\
\hline & Catholic & Re-formed & $\begin{array}{l}\text { Other } \\
\text { Christian }\end{array}$ & $\begin{array}{l}\text { Other } \\
\text { religions }\end{array}$ & None & Un-known & \\
\hline Geneva (GE) & 34.5 & 9.4 & 5.4 & 8.7 & 38.9 & 3.1 & 1 \\
\hline Neuchâtel (NE) & 23.4 & 21.1 & 5.3 & 5.6 & 42.3 & 2.3 & 2 \\
\hline Aargau (AG) & 33.4 & 25.1 & 6.5 & 7.9 & 26.2 & 0.8 & 3 \\
\hline $\begin{array}{l}\text { Appenzell } \\
\quad \text { Ausserrhoden (AR) }\end{array}$ & 72.2 & 11.4 & 4.3 & 2.4 & 8.3 & 1.4 & 3 \\
\hline Nidwalden (NW) & 66.5 & 11.4 & 2.9 & 2.9 & 15.6 & 0.8 & 3 \\
\hline $\begin{array}{l}\text { Appenzell } \\
\text { Innerrhoden (Al) }\end{array}$ & 72.2 & 11.4 & 4.3 & 2.4 & 8.3 & 1.4 & 4 \\
\hline Basel Stadt (BS) & 17.4 & 16.9 & 6.1 & 11.4 & 46.2 & 2.0 & 4 \\
\hline Glarus (GL) & 35.5 & 33.1 & 3.7 & 9.3 & 17.8 & 0.6 & 4 \\
\hline Graubünden (GR) & 45.1 & 32.7 & 4.0 & 2.6 & 14.5 & 1.1 & 4 \\
\hline Luzern (LU) & 62.4 & 10.6 & 4.2 & 5.7 & 16.4 & 0.7 & 4 \\
\hline Schaffhausen (SH) & 22.6 & 36.3 & 7.2 & 9.7 & 23.1 & 1.2 & 4 \\
\hline Schwyz (SZ) & 61.7 & 11.9 & 4.0 & 4.5 & 17.1 & 0.8 & 4 \\
\hline St. Gallen (SG) & 45.6 & 21.3 & 6.3 & 8.6 & 17.2 & 1.0 & 4 \\
\hline Thurgau (TG) & 32.7 & 33.9 & 6.3 & 7.2 & 19.2 & 0.7 & 4 \\
\hline Zug (ZG) & 50.5 & 14.7 & 5.9 & 6.2 & 21.8 & 0.9 & 4 \\
\hline Obwalden (OW) & 72.9 & 7.5 & 2.4 & 3.7 & 12.6 & 1.0 & 5 \\
\hline Solothurn (SO) & 35.7 & 21.3 & 5.1 & 8.3 & 28.7 & 0.9 & 5 \\
\hline Ticino (TI) & 67.8 & 4.1 & 5.5 & 2.8 & 17.8 & 2.1 & 5 \\
\hline Uri (UR) & 78.9 & 5.2 & 3.2 & 1.9 & 9.8 & 1.0 & 5 \\
\hline Basel Land (BL) & 27.8 & 30.3 & 5.3 & 6.7 & 28.6 & 1.3 & 6 \\
\hline Fribourg (FR) & 61.7 & 12.0 & 3.5 & 4.6 & 16.5 & 1.8 & 6 \\
\hline Valais (VS) & 72.8 & 5.9 & 3.0 & 3.8 & 12.8 & 1.7 & 6 \\
\hline Jura (JU) & 67.3 & 8.8 & 4.4 & 3.5 & 14.5 & 1.5 & 7 \\
\hline Vaud (VD) & 30.4 & 24.2 & 6.5 & 6.5 & 30.3 & 2.1 & 7 \\
\hline Bern (BE) & 15.8 & 52.1 & 6.8 & 5.6 & 18.5 & 1.1 & 8 \\
\hline Zurich (ZH) & 27.1 & 29.6 & 7.0 & 8.4 & 27.0 & 0.9 & 8 \\
\hline
\end{tabular}

(1) According to the Strukturerhebung of the Swiss Federal Office of Statistics (BFS). Accessed 3 March 2017. https://www. bfs.admin.ch/bfs/de/home/statistiken/bevoelkerung

(2) Adapted Chaves-Cann regulation scale according to Stolz and Chaves 2017 (see Appendix 1 for the scale construction). 
Disestablishment in Geneva and Neuchâtel happened at different times, for completely different reasons, and in a very different manner. In Geneva, church and state were separated in 1907. The population voted that the budget, which the state used to finance the established Protestant Church directly, should be abolished (Scholl and Grandjean 2010, 8). This was, de facto, a separation of church and state, since, at that point, the Protestant Church had to organise and finance itself. Two reasons seem to have been important. ${ }^{6}$ Firstly, the canton had received additional-Catholic-territories in 1815, but did not want to extend the establishment to Catholics, who did not accept state authority as easily as Protestants (Guichonnet and Waeber 1991). In order to stay in line with its own standards of fairness, the government thus tried to disestablish all religious groups (Scholl and Grandjean 2010, 15). Secondly, Protestants themselves did not fight disestablishment as strongly as they could have. While the majority wanted to keep the status quo, others believed that disestablishment would make the church stronger (Scholl 2010, 27). Some of the arguments of both critics and advocates of disestablishment were surprisingly like those of today's economics of religion theorists regarding the benefits of a 'free religious market'. They argued that a separated church would impose a clear doctrine of faith, obligatory donations, and greater strictness. Also, they thought, such a church would disintegrate into a multitude of smaller and stricter competing churches, explicitly citing the situation in the US (Grandjean 2010, 94). In 1945, due to the great financial problems of the churches, the state to some extent reintroduced an establishment measure by collecting the (non-obligatory) church contribution for the churches. ${ }^{7}$ By all possible measures, however, Geneva has remained the Swiss canton with the most tenuous church-state relationship from the early twentieth century to the present.

In Neuchâtel, church and state were (partly) separated in 1943. The reason was that the established Protestant Church and the non-established Free Protestant Church (that had split off from the established church in 1873) wanted to reunite. It was decided that the reunited Protestant church would be autonomous, yet still be considered an institution of public interest.' ${ }^{8}$ This recognition was extended to the Roman Catholic Church and the Christ Catholic Church. As institutions of public interest, the churches were autonomous, but could be supported by the state insofar as they solved certain problems for the state. Concretely, this meant that the three recognized churches received-jointly-CHF200,000 per year (not price indexed), that they would be tax exempt, and that they could use public school buildings to give religious instruction. ${ }^{9}$ On the other hand, the churches were to be financed only by an optional 'church contribution' that the state would collect, but that members could pay, pay only partly or not pay at all. A new version of this regulatory scheme was introduced in 2001, when the amount of the subvention was raised to CHF1,500,000. ${ }^{10}$ Thus disestablishment did not go as far in Neuchâtel as it did in Geneva, but it was much more pronounced than in all the other Swiss cantons.

In summary, while there is no absolute separation of church and state in the cantons of Geneva and Neuchâtel, they are the cantons with the by far strongest disestablishment. This is true both when seen in historical perspective and when measuring with a regulation scale. It is thus in these two cantons that we should expect signs of religious revival.

\section{Effects of disestablishment}

In the following, I examine the effects of disestablishment both on the churches that were suddenly separated from the state and on their competitors, to see if they behaved as the economic model predicts. 


\section{Strictness}

Did the formerly established churches-as the economic theory anticipates-increase their theological and moral strictness to keep out 'free riders' and thus become more competitive? The simple answer is 'no, although some members attempted to do so'.

In Geneva, immediately after disestablishment in 1907, the governing body of the Protestant Church was very clear that it did not want to tighten its membership criteria, but that it would do everything to retain its relaxed attitude and its character of a 'folk church' that was 'open to all' (Grandjean 2010, 87; Amsler 1986, 19). ${ }^{11}$ One of the clearest signs of this aim was a revised definition of membership. While the evangelical faction of the Church supported the option of a very clear-cut and exclusive definition, the version finally adopted on 12 June 1908 was a folk church definition that made membership a function of individual opinion:

Are members of the National Protestant Church of Geneva (ENPG) all the Protestants of Geneva and all the Protestant inhabitants of the Canton who consider themselves to belong to this church. (as quoted in Amsler 1986, 29)

In a similar vein, the new church constitution did not include any declaration of faith that members would have to adhere to and stipulated only a moral obligation to contribute financially. Not only were the adherents of this kind of folk church model in the majority at the birth of the newly separated church, but they have also successfully defended this model against opposition to the present day.

To give just one example: in the 1930s, pastor Paul Tournier proposed greater strictness in the Protestant Church of Geneva, suggesting that church members should have to declare their desire to join in writing, that only accepted members should be able to vote, that the church should ask members to be committed, and that non-paying members should be excluded from the church (Amsler 1986, 116-117). According to Tournier, a stricter church would prove to be more attractive and better able to meet the challenges of disestablishment:

It is a great illusion to think that the church will be the more attractive the less it demands from its members [...]. The more the church demands from its members in terms of activities and commitment, the more there will be a visible boundary between those who really work for the church, and the majority that is indifferent to its work. (as quoted in Amsler 1986, 117))

This proposal was ferociously opposed by a movement led by the conservative centrist Paul Pictet who argued that the Church should continue to be there 'for everybody'. When asked by his daughter why he fought so much for this cause-although he never went to church-he is said to have answered:

Well, that's exactly it! I represent the people who do not go to church, but who are Protestants because they are of Geneva origins. (as quoted in Amsler 1986, 119)

Unsurprisingly, the relaxed position won the battle and the Protestant Church of Geneva remained a folk church-as it would many times in the future when the question of strictness vs. laxity arose.

In Neuchâtel, just as in Geneva, the disestablished Reformed Church (EREN) did not become a strict confessional church, but remained essentially a folk church of low strictness. This is evident in its definition of who a member is, which is "all those who see themselves as Reformed Christians" in the canton, without the church or any other institution validating such a decision (Constitution of EREN, art. 4; Bader 2008, 26). It is also visible in the description of the Church's function, which is to be "at the service of all the inhabitants of 
the Neuchâtel area through the proclamation of the Gospel and Diaconia" (EREN 2014, art. 4). ${ }^{12}$ To my knowledge, there have not been any serious attempts to transform the EREN into a confessional church.

Following the discussions about membership and strictness in the Protestant Church of Geneva and the Eglise Réformée Evangélique de Neuchâtel through the decades, it becomes clear that the folk church model in both cases has never been in any great danger. ${ }^{13}$

\section{Evangelisation}

We may grant that the formerly established churches remained folk churches, but still ask whether the predictions of the economic model concerning evangelisation might hold. In an economic perspective, one could suspect that even folk churches might-when left to their own devices-be more competitive, outgoing, and growth-oriented than under state control. We find that formerly established churches have indeed reacted with-at least some-specific attempts at evangelising and marketing, but with little or no success.

In Geneva, several leaders of the Protestant Church of Geneva suggested, especially in the 1920s, that the financial problems could only be solved with increasing evangelisation. According to the member of the governing body Louis-Elie Millenet, the church needed a "real religious awakening, conversions en masse" (as quoted in Amsler 1986, 71, French in original, my translation). A 'commission of awakening' was created in 1923 and put to work, but its recommendations were all rejected and the commission was dissolved immediately. Nevertheless, the problem seemed pressing, so the Protestant Church created an 'evangelisation commission' and started organising evangelisation conferences in 1924, a task given to a professional evangelist (Henri Russillon) who held 183 meetings in the period of 1925 to 1927. Other evangelists were encouraged by the Protestant Church to work in Geneva, among them the famous Catherine Booth-Clibborn of the Salvation Army. Furthermore, the Church created a special 'period of recruitment' in the year and a special officer of recruitment. Yet the tangible results of all these measures were disappointing: 65 new members in 1925. The church abandoned its evangelisation efforts (Amsler 1986, 72; Chenevière 1959, 70) and put more emphasis on social activities in the 1930s. New evangelising activities could be seen in the 1950s, but again with rather limited success (Chenevière 1959, 73). From the 1960s, the Church mainly tried to seek large donations from wealthy donors and legacies. ${ }^{14}$ Since 2000, the Protestant Church of Geneva has been engaging in what may be called 'folk church marketing. The goal of such marketing is not so much to convert new souls as to keep the current members in the church and to convince them of the importance of the church's activities both for society and for the members; all of this with the goal of motivating them to pay their church contributions. Thus a strategic document of 2005 entitled "A Tough Challenge" proposes to re-organise the church in response to the needs of different target groups (families, young people, the elderly), to create specific profiles for different churches in Geneva (cultural, for young people, spirituality, city church, etc.) and to engage in specific folk church missionary projects (such as being present in shopping centres) (EPG 2005). However, these activities have not been able to stop the downward trend in membership and finances.

In Neuchâtel, after disestablishment, the formerly established churches have never attempted to increase membership or membership quality through evangelising activities, but have begun to shift their focus to folk church marketing (Bader 2008, 9). Together with 
the Protestant Church of Geneva, it is here that we find the first and most clearly developed examples of folk church policies trying to 'target' specific groups of the population and to create a positive 'image' of the church. Church officials talk specifically about the importance of 'client marketing' (Bader 2008, 9). Again, the results of church marketing efforts have not had the effects for which the church had hoped.

The best-known example of folk church marketing specific to the 'separation' cantons of Geneva and Neuchâtel was the advertising campaigns by the Roman Catholic Church in Geneva and the Reformed Church in Neuchâtel after 2000. ${ }^{15}$ They used public advertisements to point to the danger of a possible vanishing of Christian culture and/or the churches and the negative consequences for society that this might entail. At the same time, they appealed to the sense of responsibility of church members to counter this danger by giving their church donations. Looking over the posters, one is struck by the often rather negative and sometimes ironic tone, which shows that church officials thought that members had the duty to make their donations, but had only limited hope that they would do so. One example, used by the Roman Catholic Church in Geneva in 2002, read: "Faith. In 2016, there may be no more priests left to preach the gospel in Geneva. But that's not a problem, a few 'SMS' [electronic messages] should do the job." Another, used in 2004, said, "So that your children will not believe that Jesus is just the name of a Brazilian soccer player, don't forget to pay your church contribution!" An example from Neuchâtel depicts a robot in pastoral robe with the caption, "Because of low income, will we have to adapt our services?" It is difficult to judge the effectiveness of these campaigns, but they certainly did not solve the financial problems of formerly established churches and they were eventually dropped (quickly in Neuchâtel, after a few years in Geneva).

Summing up this point, we can say that formerly established churches have clearly felt the need to become active concerning evangelism and marketing. They have indeed engaged in some original activities that cannot be found in their still established sister churches in other cantons. However, their evangelising and marketing activities had little success and were rather short-lived.

\section{The religious vitality of the religious field}

One might think that, while disestablishment certainly did not help the disestablished churches, it might have boosted the overall religious system. After all, the playing field had been levelled (in Geneva) or at least been made more equal than before (in Neuchâtel). The economic theory of religion would therefore lead us to expect exceptional growth of the religious competition that had previously been 'held back'. Thus, we would expect lower rates of people without any religion ('nones'), higher rates of overall church attendance, and higher percentages of 'upstart' religious groups per inhabitant. I address these hypotheses by looking at longitudinal census data, retrospective survey data, and cross-sectional congregation census data. None of these hypotheses are corroborated by the data.

Rates of 'nones'. The data clearly show that Geneva and Neuchâtel did not have lower rates of 'nones' than other cantons (see Figure 1). In both cantons, from the 1970s, the phenomenon of people without religion, the 'nones', appeared. In Geneva, the number of nones rose from 3 in 1970 to 23 in 2000; in Neuchâtel, the number rose from 2 in 1970 to 22 in 2000. If anything, the rise was even more pronounced in Geneva and Neuchâtel than in 


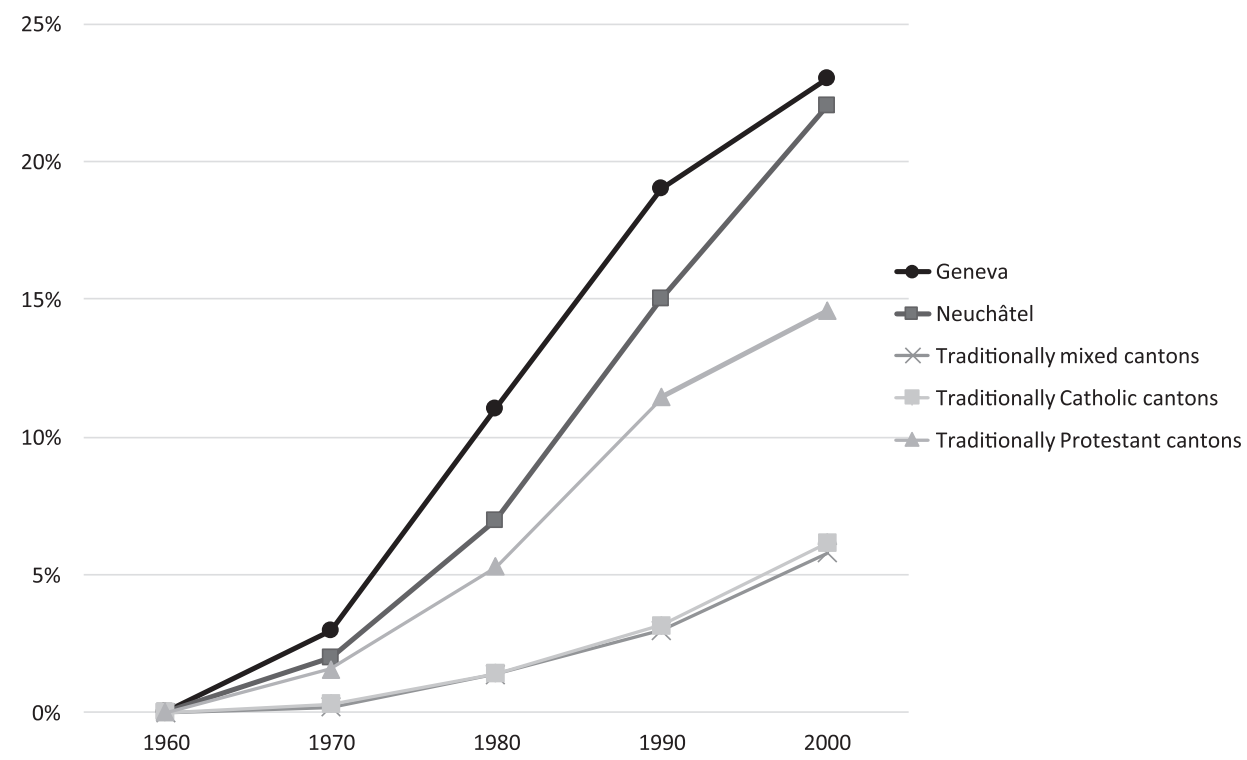

Figure 1. Percentage of individuals with no religion in Swiss cantons with different confessional traditions. Note: Census Data from Bovay 2004. This figure does not include the OFS data for 2015 presented in Table 1, since the numbers are not directly comparable. The overall result is similar, with or without inclusion of the 2015 data.

most other Swiss cantons and more like the developments in other traditionally Protestant cantons than in traditionally Catholic or mixed cantons.

Overall rates of church attendance. The cantons of Geneva and Neuchâtel did not have higher overall rates of church attendance than other cantons. Figure 2 shows the church attendance rates of respondents' mothers when the respondents were twelve years old. Since respondents were born in different decades, this item creates data that span the period between the 1930s and 2000. ${ }^{16}$ Again, religious practice in Geneva and Neuchâtel is close to that of other Swiss cantons with a traditionally Protestant background and tends to be lower than in cantons with a traditionally Catholic background. The overall secularisation trend seems to be the same as in other cantons.

Number of 'upstart' religious groups. If the theory held, we would expect a higher ratio of non-established ('upstart') groups to develop in cantons where disestablishment has gone farthest. Using a congregation census by Stolz et al. (Stolz et al. 2011), I calculated the number of non-established Christians, non-Christian, and Other/NRM (groups that did not fall into any of the larger religious categories) congregations per 10,000 habitants. The result is again negative. Neuchâtel and Geneva do not show a clear pattern of more nonestablished groups than other cantons (see Figure 3). If anything, Figure 3 shows the scarcely surprising fact that non-established and new groups are more often to be found in urban than in rural areas. Thus, they are less often to be found in rural cantons such as Obwalden (OW), Nidwalden (NW), Jura (JU) or Valais (VS). This also explains the outlier Basel Stadt (BS); this half-canton is a city; in cities, non-established groups are more prevalent. We would find similar results for other large Swiss cities such as Zurich or Lausanne.

The overall result of this section is that disestablishment has raised the religious vitality neither of the formerly established churches nor of the religious competitors, neither in the canton of Geneva nor in the canton of Neuchâtel. 


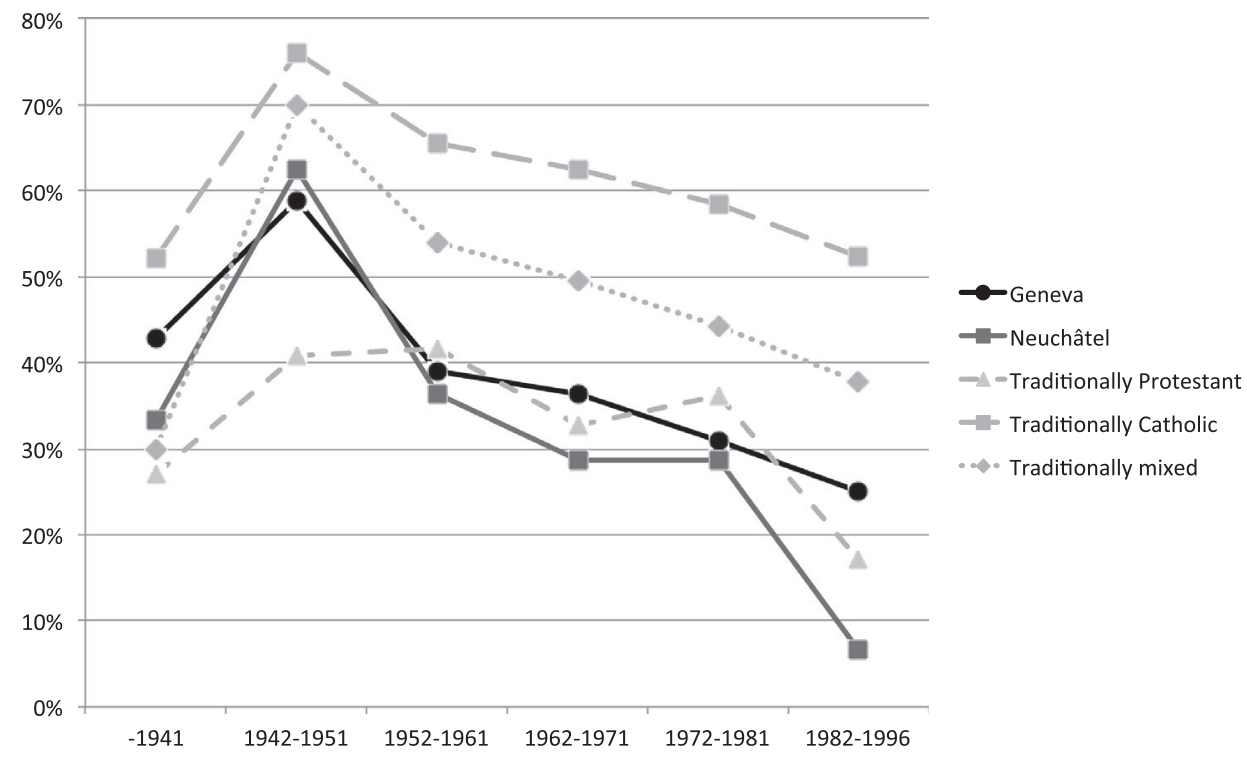

Figure 2. At least weekly church attendance of mothers of respondents in different decades in Swiss cantons with different confessional traditions.

Note: ISSP Data 1999.

6.00

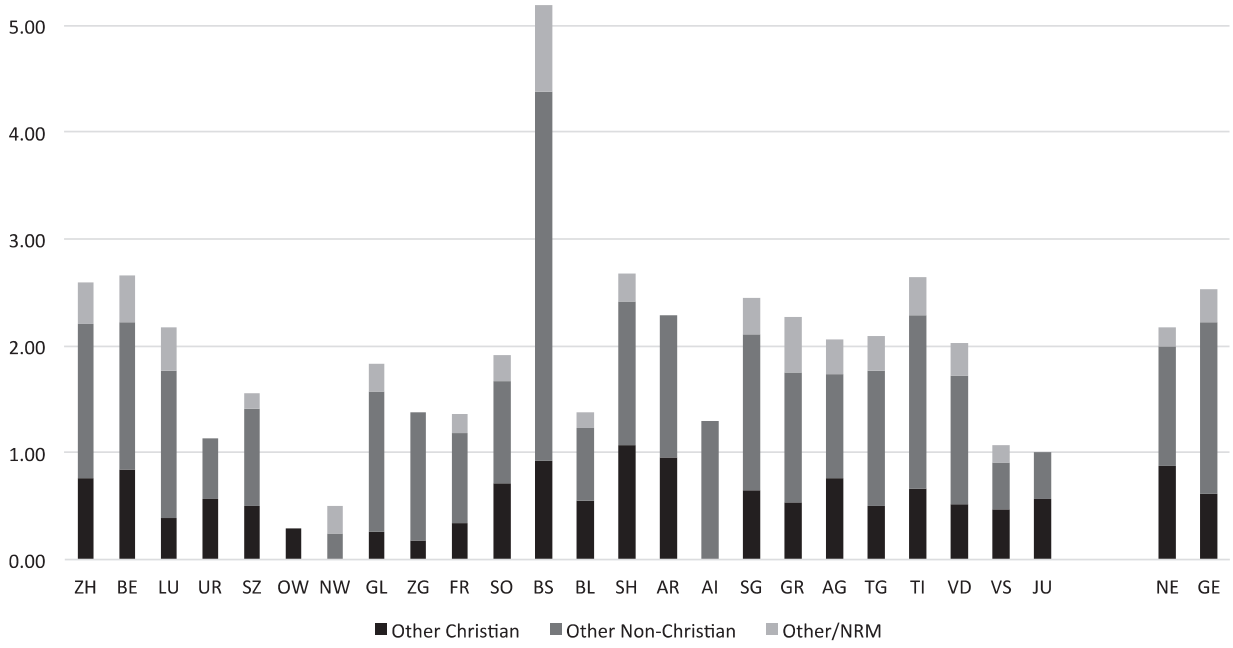

Figure 3. Congregations per 10,000 inhabitants in 2008/2009: Other Christian, Other Non-Christian, Other/NRM Congregations in different cantons.

Notes: $\mathrm{ZH}=Z$ Zürich, $\mathrm{BE}=\mathrm{Bern}, \mathrm{LU}=\mathrm{Luzern}, \mathrm{UR}=\mathrm{Uri}, \mathrm{SZ}=S$ chwyz, OW=Obwalden, NW=Nidwalden, $\mathrm{GL}=\mathrm{Glarus}, \mathrm{ZG}=\mathrm{Zug}$, $\mathrm{FR}=$ Fribourg, $\mathrm{SO}=$ Solothurn, $\mathrm{BS}=\mathrm{Basel} \mathrm{Stadt}, \mathrm{BL}=$ Basel $\mathrm{Land}, \mathrm{SH}=\mathrm{Schaffhausen}, \mathrm{AR}=$ Appenzell Ausserrhoden, $\mathrm{Al}=$ Appenzell Innerrhoden, $\mathrm{SG}=$ Sankt Gallen, $\mathrm{GR}=\mathrm{Graubünden}, \mathrm{AG}=$ Aargau, $\mathrm{TG}=$ Thurgau, $\mathrm{Tl}=\mathrm{Ticino}, \mathrm{VD}=\mathrm{Vaud}, \mathrm{VS}=\mathrm{Valais}, \mathrm{JU}=\mathrm{Jura}$, $\mathrm{NE}=$ Neuchâtel, $\mathrm{GE}=$ Genève. 


\section{Income}

There was, however, one domain in which disestablishment had very visible consequences for formerly established churches: their income. In other cantons where establishment prevailed and where established churches could normally use a church tax financing system, established churches remained rich (Marti, Kraft, and Walter 2010, 31); in Geneva and Neuchâtel, they became poor.

In Geneva, a slight deficit of the Protestant church at the end of the year had never been unusual, but right after disestablishment, this deficit began to rise spectacularly. In 1918, it had grown to CHF86,856 and the Protestant Church of Geneva had seriously to think about decreasing the salary of the pastors. At that point, one member of the leading body of the church, Henri de Morsier, exclaimed:

It would be a scandal for our religious folks if it came to this [...]. Does our population really want us to reduce the salary of the pastors who are already not paid enough? In Zurich, the road cleaners are better paid than our pastors. (as quoted in Amsler 1986, 65)

Fifteen years later, the deficit had reached an all-time high of CHF204,151 at the end of the year. In 1934 and again in 1936, the salaries of the pastors were indeed reduced by 4-7\% and 5\%, respectively (Amsler 1986, 103).

As already mentioned, the situation was so difficult that the churches could convince the state to provide them with financial assistance. Since 1945, the state has collected the (optional) church contribution for the Protestant, Roman Catholic, and Christ Catholic churches (Amsler 1986, 162). The current financial situation of the Protestant Church of Geneva can only be described as very difficult. It has steadily reduced its full-time pastors: from 106 in 1970 to 67 in 2000 and to just 60 in 2014. Its current planning anticipates that the Church will have 40 full-time pastors in $2020 .{ }^{17}$ The Church has also begun to sell off church property and has sold church buildings to pay its debts. A document from 2013 states:

The situation of the Protestant Church of Geneva today has never been so serious. [...] The problem is not just financial or temporal: it affects the very core of our institution [...]. Its capacity to proclaim the gospel widely and effectively is seriously damaged. [...] In these circumstances, the church must deal with discouragement and confusion, for it faces the unthinkable: the possibility of bankruptcy $[\ldots] .{ }^{18}$

The financial situation of the Roman Catholic Church in Geneva is not any more comfortable. Pierre Regad, General Secretary of the Roman Catholic Association of Geneva, noted in 1997 that only 13 of the Catholic households in Geneva paid their church contributions (all or part of it) and that "the average payment is steadily dropping" (Regad 1997, 149).

Just as in Geneva, in Neuchâtel, the formerly established Protestant Church soon found that, after disestablishment in 1943, it experienced financial problems without state financing. Clearly, the CHF200,000 that were not indexed and had to be divided between the three churches of public interest did not help the Church very much. Furthermore, the optional church contributions did not roll in. In 1954, it was proposed that the state subsidy should be increased, a proposal that did not lead anywhere. In 1960, it was proposed that Neuchâtel introduce an obligatory church tax as most other cantons did, but the people voted against it with an impressive majority of 78\% (Zen-Ruffinen and Guy-Ecabert 1997, 163). In 1965, another proposition in the Grand Conseil wanted to raise the public subsidy-again without success. In 2008, the council president of the synod of the Protestant Church of Neuchâtel wrote: 
We do not have enough liquid assets to pay our bills; our financial reserves have been drained, and we won't be able to cover the foreseeable deficit. Our financial structure is unrealistic: our resources do not allow our current expenditure. (Bader 2008, 4)

Since then, the situation has become worse, not better. In 2011, one of the foremost donors of the Protestant Church of Neuchâtel, the cigarette producer Philip Morris, stopped making its 'church donation' (CHF850,000, almost 10\% of the Church's budget). ${ }^{19}$ The Protestant Church of Neuchâtel has reduced the number of full-time pastors from 106 in 1970 to 67 in 2000 and to 31 in 2012. ${ }^{20}$ Just as the Protestant Church of Geneva did, the Protestant Church of Neuchâtel has begun to sell off a lot of church property.

In general, the financial problems of the Protestant Church of Geneva and the Protestant Church of Neuchâtel can easily be explained. Because of the separation of church and state, the churches are basically financed by optional church contributions which can be viewed as donations. Unfortunately for the churches, as their overall membership decreases, so does the number of members who pay any amount-and especially the number of members who pay the full amount of the church contribution. Thus, while, in 1974, the Protestant Church of Neuchâtel had 46,100 members, of whom 48\% paid some (often small) amounts and $36.5 \%$ paid the full amount, in 2006, the Church was left with only 32,800 members, of whom $31.8 \%$ paid some amounts and only $3.3 \%$ paid the full amount. The strikingly lower income of the Geneva and Neuchâtel churches can be seen in Figure 4 where their income per member is compared with their sister churches in other cantons. For example, Protestant churches in traditionally Protestant cantons received on average CHF344.00 per member per year, while in Neuchâtel they received around four times less-only CHF85.00.

To recapitulate this point: disestablishment has very quickly led to immense financial problems for the formerly established churches, since most members of folk churches

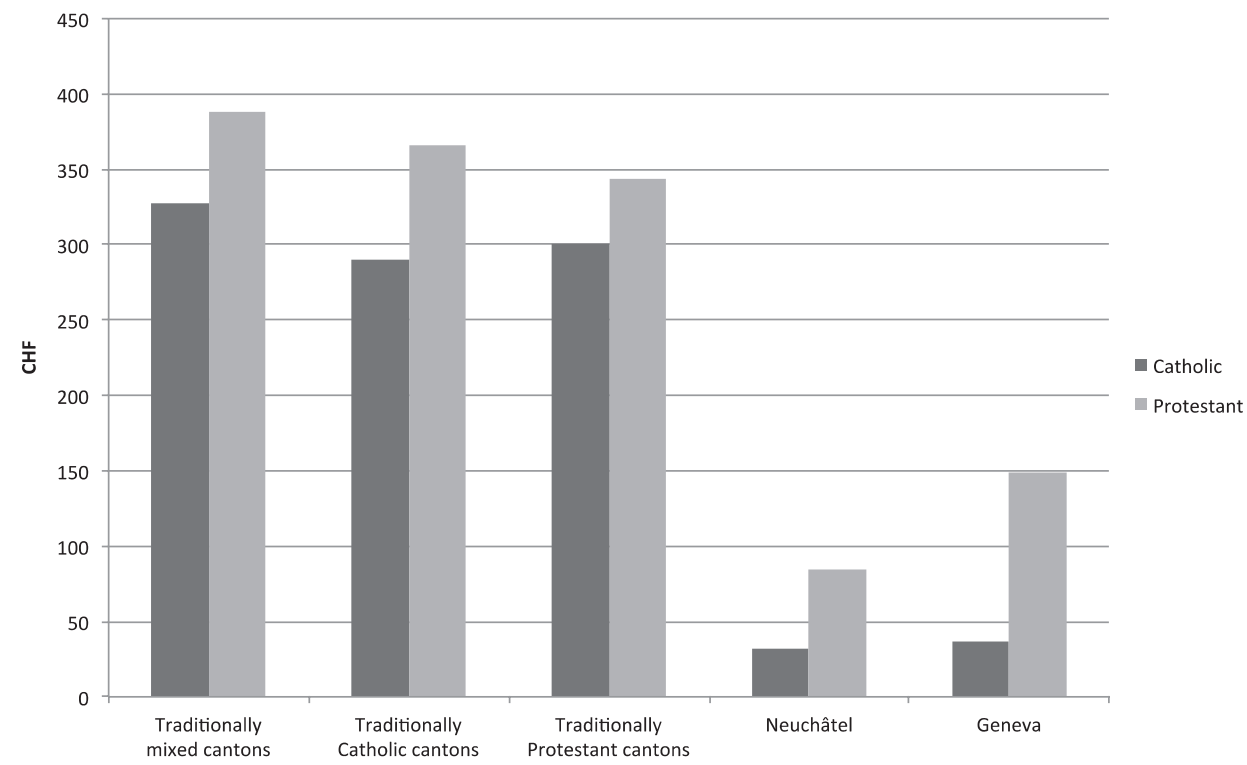

Figure 4. Church tax/contribution revenue per member in 2017 in Protestant and Catholic churches in different cantons.

Note: These data are taken from Marti et al. 2010, 31. Omitted are cantons with state budget financing, that is, where the state directly finances established churches (without a church tax or donation system). 
are distanced, having an incentive to 'free ride' and paying little or none of their church contributions. ${ }^{21}$

\section{Conclusion}

In this article, I have examined a well-known theoretical idea put forward by scholars in contemporary economics of religion: that disestablishment leads to more religious vitality. To achieve this, I have described the effects of disestablishment on strictness, evangelisation, marketing, membership, attendance, and overall religious vitality in the two Swiss cantons that have gone farthest with disestablishment: Geneva and Neuchâtel. None of the hypotheses suggested by economists of religion were confirmed. Instead, my historical analyses have led me to identify four theoretical points that seem to have been important in these two cases and that may be useful for future research.

Firstly, the formerly established churches did not become stricter. While some church leaders suggested requiring confessional statements and stricter moral standards for their members, these attempts were quickly defeated. A clear majority of church members and leaders wanted their church to remain a 'folk church'-open to everybody. The mechanism at work is simple: the majority of members who could vote on such questions were distanced members who would have voted themselves out of power and membership if they had agreed to increasing strictness. This seems to be a general point that explains why democratically organised folk churches have great difficulty in becoming more focused.

Secondly, the formerly established churches exhibited specifically focused but relatively unsuccessful evangelising and marketing efforts that were not observable in any of the sister churches. The Protestant Church of Geneva tried some unsuccessful evangelicaltype evangelising in the 1920s and 1930s. After 2000, formerly established churches tried innovative (but again rather unsuccessful) church marketing. The reason for this finding seems to be the following: folk churches with a financing system involving contributions are under great pressure to keep contributions up and will try to find ways to stabilise income. Both evangelical-type evangelising and folk church-type marketing are, however, difficult, which is why they are often done half-heartedly and easily abandoned. Evangelical-type evangelism is difficult for folk churches for several reasons: they have no clear ideology of 'conversion/salvation'; they lack a distinct group of firm believers to receive and stabilise new converts; they fear 'manipulating members'. Folk church-type marketing is equally difficult. Its goal is to retain distanced members by suggesting that the values and services of the church justify major donations. Since the function of the churches for society and for individuals is rather fuzzy, such marketing is rarely successful.

Thirdly, there was no increased religious vitality in the two cantons, compared to other Swiss cantons. Instead, secularisation progressed almost exactly as it did elsewhere. Remarkably, disestablishment not only failed to vitalise formerly established groups, it was also incapable of boosting the non-established competitors. One possible explanation is that, in a context of relatively low religious demand, the disestablishment of certain churches will not help their competitors. No crowding out can be alleviated since-given lack of demand-there has been no crowding out in the first place.

However, I found, fourthly, that disestablishment was not without effect for formerly established churches in Geneva and Neuchâtel: it led to a dramatic decrease in income. It seems that, when folk churches are forced to adopt a voluntary church contribution system 
(donations), they will become poor. The mechanism involved is again simple. Since most members of folk churches are distanced members, they will have an incentive to 'free ride'. They can remain members and retain the option of benefiting from church services in case of need, even though they pay little or nothing. Since they are only distanced members, there are no sanctions. The overall effect is a very low income for churches with a voluntary contribution system, compared with churches with an obligatory church tax.

These are the four theoretical points that help to explain why the model advanced by the economics of religion fails to account for the religious development in the Swiss cantons of Geneva and Neuchâtel. While they apply to the Swiss cases, I suspect that they may be generalised to elucidate other cases of disestablishment and folk church behaviour. I therefore welcome studies that replicate these findings in other regions and countries.

\section{Notes}

1. For a critical introduction see De Graaf 2013.

2. For the purposes of this article, I define establishment as a preferential treatment by the state of one or more religious groups, their members or their institutions. This preferential treatment may take many forms, including paying salaries to clergy, collecting church taxes, discouraging religious competitors or giving preferential access to positions in schools, hospitals, media or the military. (See also Stolz and Chaves 2017)

3. In the article by Rodney Stark and Laurence Iannaccone that applies the theory to Europe (Stark and Iannaccone 1994), there is no specific proposition claiming that deregulation should lead folk churches to become stricter. However, their description of the Swedish folk church under the heading of "Protestant Monopolies" clearly implies that they see inclusive and lax folk churches as products of strong regulation that have to change their behaviour to survive if their privileged situation is abolished. The same reasoning is implied by Iannaccone's work on the strength of strict churches (Iannaccone 1994) as well as proposition 96 of the general theory by Stark and Roger Finke (Stark and Finke 2000, 216).

4. There are, however, also studies that test the economic approach at the congregational level, especially in research on the effects of strictness. See, for example, Olson 2005, 2001; Thomas and Olson 2010.

5. See also the response by Stark and Iannaccone (Stark and Iannaccone 1996) and the rejoinder by Lechner (Lechner 1996b).

6. A third reason sometimes given is the influence of France, where church and state were separated in 1905. While one cannot rule out some kind of 'contamination', the causes of the separation seem to have been very different in the two cases.

7. Retaining $2 \%$ of the contributions for the cost of collection (see http://www.impotecclesiastique. $\mathrm{ch} / ? \mathrm{q}=\mathrm{GE}$, accessed 26 July 2014).

8. Constitution of the canton of Neuchâtel, Art. 71, alinea 1.

9. For the Protestant Church of Neuchâtel, it was added that it could use public church buildings free of charge (see Zen-Ruffinen and Guy-Ecabert 1997; Beljean 2001, 69).

10. See http://rsn.ne.ch/DATA/program/books/rsne/htm/18110.htm, accessed 19 November 2016.

11. It wanted, as church members expressed it at the time, to continue to be of 'national' (which really means 'cantonal') importance. In fact, the church dropped the adjective 'national' from its name only in 2000. The 'Église Nationale Protestante de Genève' (ENPG) became the 'Église protestante de Genève' (EPG). (See http://www.protestant.ch/enpg, accessed 28 July 2014)

12. Reading the constitution of the Eglise réformée évangélique du canton de Neuchâtel (EREN), one notices that this church is a little less liberal than the Protestant Church of Geneva. Still, it clearly remains a very low-strictness folk church (see https://www.eren.ch/documentation/ wp-content/uploads/sites/2/2015/11/constitution-eren.pdf, accessed 20 November 2016). 
13. Additional evidence comes from sister churches in the cantons where surveys among church members showed that overwhelming majorities of $81 \%$ (survey from 2004 in the canton of Vaud) and 95\% (survey from 1996 in the canton of Basel Land) of church members of Protestant churches were in favour of keeping the folk church model against the proposed change to a confessional church (Stolz and Ballif 2010, 83).

14. In the expert interviews, it was mentioned several times that especially the Eglise protestante de Genève (EPG) covered its debts throughout the twentieth century due to some very wealthy Protestant donors who had the time and money to endow the church. However, these donors have become increasingly rare.

15. See the article "Dieu vous le rendra! Pour remplir leurs caisses, les Églises de Genève deviennent expertes en marketing religieux" in Tribune de Genève of 23 September 2011.

16. These data are produced by using the 1999 RLS/ISSP cross-sectional survey and analysing the retrospective question: "When you were a child, how often did your mother attend religious services?" I give the rates of mothers and not of respondents since the indicator 'service attendance as a child at the age of 11-12 years' confounds personal religiosity and parental religious socialisation efforts. These retrospective data are less reliable than longitudinal data collected in the different decades. However, the overall secularisation trends that we find are in complete accord with all the other data that we have on religiosity in Switzerland. (See Stolz et al. 2016, 151-153; for a discussion of this kind of retrospective data, see Franck and Iannaccone 2014)

17. According to the "Rapport à l'intention du Consistoire ainsi que des Conseils de paroisse et ministère, de la Compagnie des pasteurs et des diacres", document de travail interne du 14 juin 2013.

18. According to the "Rapport à l'intention du Consistoire ainsi que des Conseils de paroisse et ministère, de la Compagnie des pasteurs et des diacres", document de travail interne du 14 juin 2013: 1-2.

19. See http://www.eren.ch/fileadmin/user_upload/resources/20101127-CIC-ArcInfo.pdf, accessed 28 July 2014.

20. The information on the numbers of pastors is from Office fédéral de statistique (OFS), "Erwerbstätige mit ausgewählten beruflichen Tätigkeiten (Berufsart 832.01 Ordinierte Geistliche, Pfarrer/innen).” (See http://www.eren.ch/fileadmin/user_upload/resources/ 20101127-CIC-ArcInfo.pdf, accessed 28 July 2014)

21. Recent work by Sidsel Kjems suggests that differences in church financing such as those examined here for Switzerland also help to explain the great differences in income between the rich national churches of Finland, Sweden, and Denmark, on the one hand, and the much poorer national churches of Norway, Iceland, England, and Scotland, on the other hand (Kjems 2016).

\section{Acknowledgements}

I thank Aurélie Netz for help with the research and Mark Chaves and the two anonymous reviewers of the Journal of Contemporary Religion for valuable comments on an earlier version of this article. Christine Rhone helped me with the English version. This work was supported by the Swiss National Fund (Grant 405840-115719/1).

\section{Disclosure statement}

No potential conflict of interest was reported by the author.

\section{Notes on contributor}

Jörg Stolz is professor of the sociology of religion at the University of Lausanne, Switzerland. CORRESPONDENCE: ISSR, Anthropole, Université de Lausanne, CH-1015 Lausanne, Switzerland. 


\section{References}

Amsler, Frédéric. 1986. "Esquisse de l'histoire de l'Eglise nationale protestante de Genève de la suppression du budget des cultes à l'immédiat après-guerre: étude fondée sur le Mémorial des séances du Consistoire de l'Eglise nationale protestante de Genève." Mémoire de diplôme: Faculté autonome de théologie protestante, Université de Genève.

Bader, Gabriel. 2008. L'EREN en question: travail de fin de formation en vue de l'obtention d'un CAS en gestion publique. Formation continue de l'Etat de Neuchâtel. Neuchâtel. Unpublished manuscript.

Beljean, Jean-Jacques. 2001. "Distance et proximité: une histoire de concordat État-Églises en Pays de Neuchâtel." In Schweizerisches Jahrbuch für Kirchenrecht, edited by Jakob Frey, Dieter Kraus, Wolfgang LIenemann, and René Pahus de Mortanges, 65-74. Bern: Peter Lang.

Bovay, Claude. 2004. Le paysage religieux en Suisse. Neuchâtel: OFS.

Bruce, Steve. 1993. "Religion and Rational Choice: A Critique of Economic Explanations of Religious Behavior." Sociology of Religion 45 (2): 193-205.

Bruce, Steve. 1999. Choice and Religion: A Critique of Rational Choice Theory. Oxford: Oxford University Press.

Campiche, Roland J. 2004. Die zwei Gesichter der Religion: Faszination und Entzauberung. Zürich: TVZ.

Chaves, Mark, and David E. Cann. 1992. "Regulation, Pluralism, and Religious Market Structure." Rationality and Society 4 (3): 272-290.

Chaves, Mark, and Philip S. Gorski. 2001. "Religious Pluralism and Religion Participation." Annual Review of Sociology 27: 261-281.

Chenevière, Charles. 1959. L'Eglise de Genève de 1909 à 1959: esquisse historique de son organisation suivie des diverses modifications de sa constitution, de la liste de ses pasteurs et professeurs et d'une table biographique. Genève: Labor et Fides.

De Graaf, Nan Dirk. 2013. "Secularization: Theoretical Controversies Generating Empirical Research." In Handbook of Rational Choice Social Research, edited by Rafael Wittek, Victor Nee, and Tom A. B. Snijders, 322-354. Redwood, CA: Stanford University Press.

EPG. 2005. Projet EPG 2005: un formidable défi. Missions. Priorités. Principes d’organisation. Répartition des forces ministérielles. Rapport confidentiel rédigé par le groupe projet EPG 2005. Genève. Unpublished manuscript.

EREN (Eglise réformée évangélique du canton de Neuchâtel). 2014. "Constitution of 1980 (last updated in 2014)." Accessed 20 November 2016. https://www.eren.ch/documentation/wp-content/ uploads/sites/2/2015/11/constitution-eren.pdf

Fox, Jonathan, and Ephraim Tabory. 2008. "Contemporary Evidence regarding the Impact of State Regulation of Religion on Religious Participation and Belief." Sociology of Religion 69 (3): 245-271.

Franck, Raphaël, and Laurence R. Iannaccone. 2014. "Religious Decline in the 20th Century West: Testing Alternative Explanations." Public Choice 159 (3-4): 385-414.

Grandjean, Michel. 2010. "La portée des arguments de 1907: coup d’oeil dans le rétroviseur de léglise nationale protestante de Genève." In L'Etat sans confession: la laïcité à Genève (1907) et dans les contextes suisse et français, edited by Sarah Scholl and Michel Grandjean, 87-102. Genève: Labor et Fides.

Guichonnet, Paul, and Paul Waeber. 1991. Genève et les Communes réunies: la création du canton de Genève (1814-1816). Genève: Comité d'organisation des fêtes du 175e anniversaire du rattachment des Communes réunies au canton de Genève.

Iannaccone, Laurence R. 1991. “The Consequences of Religious Market Structure: Adam Smith and the Economics of Religion." Rationality and Society 3 (2): 156-177.

Iannaccone, Laurence R. 1994. "Why Strict Churches are Strong." American Journal of Sociology 99 (5): 1180-1212.

Iannaccone, Laurence R. 1998. "Introduction to the Economics of Religion." Journal of Economic Literature 36 (3): 1465-1495.

Kjems, Sidsel. 2016. "Comparing the Financial Situation of Seven Majority Churches in Northern Europe." Paper presented at the 23rd Nordic Conference for the Sociology of Religion, Helsinki, 17-19 August. 
Lechner, Frank J. 1996a. "Secularization in the Netherlands?" Journal for the Scientific Study of Religion 35 (3): 252-264.

Lechner, Frank J. 1996b. "Rejoinder to Stark and Iannaccone: 'Heads, I Win...': On Immunizing a Theory." Journal for the Scientific Study of Religion 35 (3): 272-274.

Marti, Michael, Eliane Kraft, and Felix Walter. 2010. Dienstleistungen, Nutzen und Finanzierung von Religionsgemeinschaften in der Schweiz. Bern: Rüegger Verlag.

McCleary, Rachel M., and Robert J. Barro. 2006. "Religion and Political Economy in an International Panel." Journal for the Scientific Study of Religion 45 (2): 149-175.

Monnot, Christophe, and Jörg Stolz. 2014. "The Diversity of Religious Diversity: Using Census and NCS Methodology in Order to Map and Assess the Religious Diversity of a Whole Country." In Religious Pluralism: Framing Religious Diversity in the Contemporary World, edited by Giuseppe Giordan and Enzo Pace, 73-91. Cham: Springer.

Olson, Daniel V. A. 2001. "Variations in Strictness and Religious Commitment within and among Five Denominations." Journal for the Scientific Study of Religion 40 (4): 757-764.

Olson, Daniel V. A. 2005. "Free and Cheap Riding in Strict Conservative Churches." Journal for the Scientific Study of Religion 44 (2): 123-142.

Pahud de Mortanges, René. 2007. "System und Entwicklungstendenzen des Religionsverfassungsrechts der Schweiz und des Fürstentums Liechtenstein." Zeitschrift für evangelisches Kirchenrecht 52 (3): 495-523.

Pollack, Detlef, and Gergely Rosta. 2015. Religion in der Moderne: Ein internationaler Vergleich. Frankfurt a.M: Campus.

Regad, Pierre. 1997. "Comment l'Eglise catholique romaine à Genève vit-elle la séparation ÉgliseÉtat?” In Rapports Eglise-Etat en mutation, edited by Adrian Loretan, 147-154. Freiburg: Universitätsverlag Freiburg Schweiz.

Scholl, Sarah. 2010. "Contrôler ou séparer: quel rôle pour l'Etat en matière religieuse à Genève (1870-1880)?” In L'Etat sans confession: la laïcité à Genève (1907) et dans les contextes suisse et français, edited by Sarah Scholl and Michel Grandjean, 21-31. Genève: Labor et Fides.

Scholl, Sarah, and Michel Grandjean. 2010. "Introduction." In L'Etat sans confession: la laïcité à Genève (1907) et dans les contextes suisse et français, edited by Sarah Scholl and Michel Grandjean, 7-20. Genève: Labor et Fides.

Smith, Adam. (1776) 2008. The Wealth of Nations. Radford: Wilder Publications.

Spickard, James V. 1998. "Rethinking Religious Social Action: What is 'Rational' about Rational Choice Theory?" Sociology of Religion 59 (2): 99-115.

Stark, Rodney, and Roger Finke. 2000. Acts of Faith: Explaining the Human Side of Religion. Berkeley, CA: University of California Press.

Stark, Rodney, and R. Laurence Iannaccone. 1994. “A Supply-side Reinterpretation of the 'Secularization of Europe"' Journal for the Scientific Study of Religion 33 (3): 230-252.

Stark, Rodney, and Laurence R. Iannaccone. 1996. "Response to Lechner: Recent Religious Declines in Quebec, Poland, and the Netherlands: A Theory Vindicated." Journal for the Scientific Study of Religion 35 (3): 265-271.

Stolz, Jörg. 2009. “Explaining Religiosity: Towards a Unified Theoretical Model.” British Journal of Sociology 60 (2): 345-376.

Stolz, Jörg, and Edmée Ballif. 2010. Die Zukunft der Reformierten: Gesellschaftliche Megatrendskirchliche Reaktionen. Zürich: TVZ.

Stolz, Jörg, and Mark Chaves. 2017. "Does Disestablishment Lead to Religious Vitality? The Case of Switzerland." British Journal of Sociology. Advance online publication. doi: https://doi.org/10.1111/1468-4446.12268

Stolz, Jörg, Mark Chaves, Christophe Monnot, and Laurent Amiotte-Suchet. 2011. Die religiösen Gemeinschaften in der Schweiz: Eigenschaften, Aktivitäten, Entwicklung. Schlussbericht: Collectivités religieuses, État et société. Programme national de recherche PNR 58. Accessed 26 March 2018. http://www.snf.ch/SiteCollectionDocuments/nfp/nfp58/NFP58_Schlussbericht_Stolz_Chaves.pdf Stolz, Jörg, Judith Könemann, Mallory Schneuwly Purdie, Thomas Englberger, and Michael Krüggeler. 2016. (Un)Believing in Modern Society: Religion, Spirituality, and Religious-secular Competition. London: Routledge. 
Thomas, Jeremy N., and Daniel V. A. Olson. 2010. “Testing the Strictness Thesis and Competing Theories of Congregational Growth." Journal for the Scientific Study of Religion 49 (4): 619-639.

Voas, David, Daniel V. A. Olson, and Alasdair Crockett. 2002. "Religious Pluralism and Participation:

Why Previous Research is Wrong." American Sociological Review 67 (2): 212-230.

Zen-Ruffinen, Pierre-Marco, and Christine Guy-Ecabert. 1997. "La séparation de l'Église et de l'État à Neuchâtel.” In Rapports Église-État en mutation, edited by Adrian Loretan, 155-166. Freiburg:

Universitätsverlag Freiburg Schweiz.

\section{Appendix 1}

\section{A1 Adapted Chaves-Cann scale for level of religious establishment}

\section{Recognition by the state}

$0=$ little or no public recognition of some but not other religious groups

$1=$ strong public recognition of some but not other religious groups

\section{Leader appointment by state}

$0=$ no

$1=$ weak; state gives symbolic recognition to appointment

2 = strong; state is employer

\section{Salaries of ecclesiastics paid by state}

$0=$ no

$1=$ yes; the state pays some or all of the salaries of pastors

\section{Ecclesiastical tax for individuals}

$0=$ no $/$ payment optional

$1=$ mandatory

\section{Ecclesiastical tax for organizations}

$0=$ no $/$ payment optional

$1=$ mandatory

\section{Church tax or donations are collected by the state}

$0=$ no

$1=$ yes

\section{Direct subsidies from the state}

$0=$ no; there are no direct financial subsidies

1 = weak; the state helps churches financially, especially concerning buildings

2 = strong; the state pays flat rates and/or per capita money per church member and/or offers pastoral houses

3 = very strong; recognized churches are financed by the state (state budget) 